\title{
The Role of Multi Dimensional EO in the Competitive Strategy - Performance Link
}

\author{
Firdaus Basbeth ${ }^{1}$, Ainon Ramli ${ }^{1}$, Muhammad Ashlyzan Bin Razik ${ }^{1}$, Rosmaizura Mohd Zain ${ }^{1} \&$ Noorshella Bin Che \\ Nawi ${ }^{1}$ \\ ${ }^{1}$ Faculty of Entrepreneurship and Business, Universiti Malaysia Kelantan, Malaysia \\ Correspondence: Firdaus Basbeth, Faculty of Entrepreneurship and Business, Universiti Malaysia Kelantan, \\ Malaysia.
}

Received: May 1, 2019

doi:10.5430/rwe.v10n2p20
Accepted: June 1, 2019

Online Published: July 7, 2019

URL: https://doi.org/10.5430/rwe.v10n2p20

\begin{abstract}
Despite the increase market in catering industry by $37 \%$ per year, the number of SME-catering service firms is only 30.000 , or only $5 \%$ from the total number of SME in 2016 . From 30,000 registered catering service company, only $10 \%$ is an active business with annual growth rate (3\%). In order to achieve competitive advantage and growth, firms will develop appropriate competitive strategy, strategy which directly relate to firm performance. The purpose of this paper is to develop a better understanding of the relationship between competitive strategy and firm performance in a different entrepreneurial orientation (EO) dimension. The statistical results revealed a) innovativeness, risk taking and proactivenss were found to have a significant and positive moderating effect on the relationship between differentiation strategy and firm performance b) innovativeness, risk taking and proactivenss were found to have a significant and positive moderating effect on the relationship between CL strategy and firm performance.
\end{abstract}

Keywords: multi dimensional, competitive strategy, performance link

\section{Introduction}

The market for SMEs catering service sector continues to experience a growth rate of $37 \%$ per year (Morisseau \& Kunni, 2014), which has great potential to develop further. However from the preliminary survey it was found that the number of SME-catering service firms is 30.000, or only 5\% from the total number of SMEs in 2016, and among them the number of active or survived catering services is only $10 \%$, with low sales growth rate (3\%). In order to be able to seize the opportunities and improving the business performance, SMEs need particular strategy that fit the resources they have and high level of EO that enable the competitive strategy to strengthen their business performance. The study has two objectives, firstly is to examine the relationship between competitive strategies: Differentiation (Diff) and Cost Leadership (CL) strategy and firm performance. Secondly, to investigate the moderating effect of innovativeness in the relationship between Diff and CL and SMEs Catering firms' performance. The study contributes to the emerging fields of strategic entrepreneurship by integrating two core concepts: EO and Competitive Strategy, it views EO as a construct that has an impact on the relationship between competitive strategy and performance. The multidimensional approach concept of EO was used to analyze the moderating effect on competitive strategy to performance link.

\section{Literature Review}

It is widely assumed that there is a clear link between strategy, and firm performance to generate above-average returns (Porter, 1980). While various frameworks are available to classify firm strategies (e.g value discipline and value innovation), the Porter model is widely accepted (Allen, Helms, Takeda, White, \& White, 2006; Sabir \& Khan 2018). Differentiation (Porter, 1980) is about creating products and services that are perceived as unique by customers; this strategy is based strongly on product innovation and marketing activities (Miller, 1988). CL requires substantial financial resources (partially needed to invest in fixed assets); it is based on learning curve benefits, economies of scale and design for manufacturing (Allen et al., 2006). Prior research also has shown for both strategy Diff and CL they are positively associated with small firm performance (Lechner \& Gudmundsson, 2014).

The three dimensions of EO within a firm was described by (Rauch et al., 2009) as the following: 1) Innovativeness involves the tendency 'to engage in creativity and support new ideas, experimentation, novelty and creative 
processes that may result in new product services as well as technological leadership via R\&D in new processes. 2) Proactiveness focuses on the 'opportunity-seeking, forward -looking perspective characterized by the introduction of new products and services in advance of the competition and action in anticipation of future demand (Lumpkin \& Dess, 2001). 3) Risk taking describes the ability of a firm to take bold actions through 'venturing into the unknown, borrowing heavily, and/or committing significant resources to undertaking in uncertain environments. Innovativeness is characterized by a strong $R \& D$ emphasis, technological leadership, the introduction of new products and the degree of changes in product or service lines (Covin \& Wales, 2012; Seddighi \& Yoon 2018). It is argued that greater innovativeness will be detrimental to the $\mathrm{CL}$ in small firms. If we assume that small businesses have a lower inclination for innovation (Runyan, Droge, \& Swinney, 2008), then comparatively, more innovativeness will enhance the Diff of small firms. In this sense, then we posit that high level of innovativeness, will negatively impact the relationship between CL and firm performance. On the other hand, we believe that the Diff and performance will be positively influenced in firms with high innovative orientations. Firm proactiveness requires a firm to make quick decisions and aggressively compete in the face of uncertainty. Thus, we expect that proactiveness will positively moderate the relationship between Diff and firm performance, and the relationship between CL and firm performance. Risk-taking is a firm's propensity to take business-related chances with regard to strategic actions in the face of uncertainty (Senam, Akpan \& Mboho 2017; Setiyawati, Iskandar \& Basar 2018). Thus, we expect that risk taking will positively moderate the relationship between Diff and firm performance, and the relationship between $C L$ and firm performance. Based on the explanation we posit that:

H1: $\quad$ Diff is positively associated with firm performance.

H2: $\quad$ CL is positively associated with firm performance.

H3 Firm innovativeness will moderate the relationship between CL and firm performance in such a way that high levels of firm innovativeness will negatively relate to performance.

H4 Firm innovativeness will moderate the relationship between Diff and firm performance in such a way that high levels of firm innovativeness will positively relate to performance.

H5 Firm proactiveness will moderate the relationship between CL and performance in such a way that high, levels of firm proactiveness will positively relate to performance.

H6 Firm proactiveness will moderate the relationship between Diff and performance in such a way that high, levels of firm proactiveness will positively relate to performance.

H7 Firm risk taking will moderate the relationship between $\mathrm{CL}$ and firm performance in such a way that high, levels of firm risk taking will positively relate to performance.

H8 Firm risk taking will moderate the relationship between Diff strategy strategy and performance in such a way that high levels of firm risk taking will positively relate to performance.

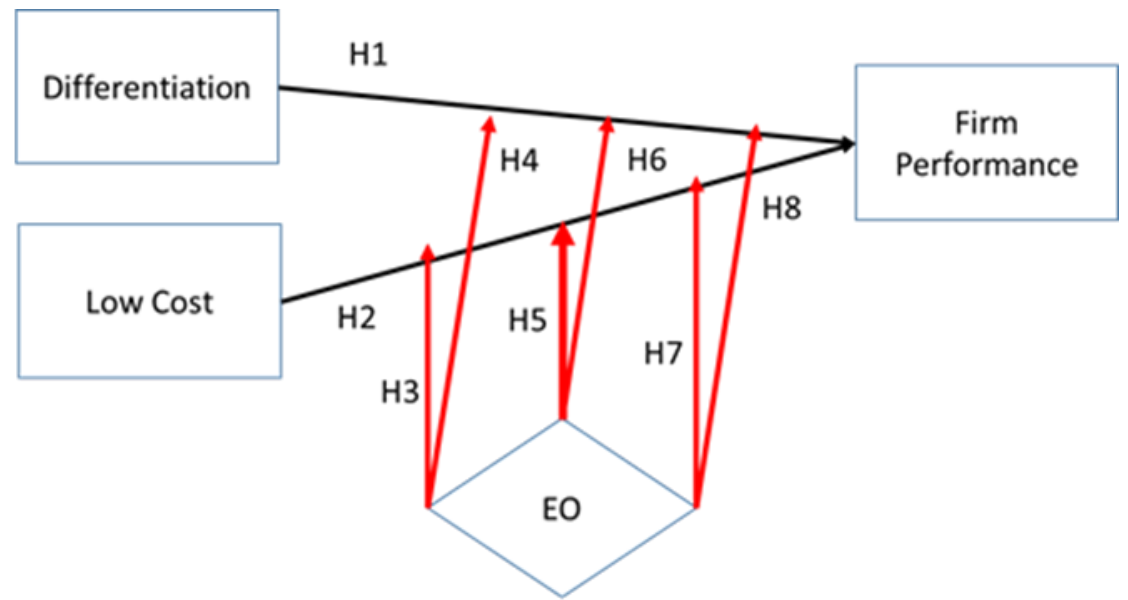

Figure 1. Research framework 


\section{Methodology}

The study utilized a cross sectional mail survey to SMEs firms in Jakarta. The sample was drawn randomly from the Jakarta association of catering firms consisted of 77 firms which had operated for at least three years and were still active. To test the theoretical model, PLS-SEM was employed for theory development and explanation of prediction of the construct (Hair Jr, Hult, Ringle, \& Sarstedt, 2014).

\section{Findings and Analysis}

The relationship between CL and Firm Performance has a weak path coefficient (0.254), and not significantly relates ( $\mathrm{p}$ values $=0.070$, and $\mathrm{t}$ stats $<1.96$.) Whereas the relationship Differentiation to Firm Performance is moderate (path coefficient 0.454 ), and significant ( $\mathrm{t}$ value 3.479 and $\mathrm{p}$ value 0.001 ). This is to confirm that for small firm choosing CL strategy to be less appropriate.

The moderating effect can be analyzed from simple slope plot generated by SmartPLS3, and showed that the higher the Innovativeness and Proactiveness the weaker the relationship between CL and Firm Performance. On the other hand, the higher the Risk Taking, the stronger the relationship between CL and Firm Performance. In the relationship between Differentiation and Firm Performance, the higher Innovativeness level entail a weaker relationship between, whilst lower innovativeness exhibit a stronger relationship. Overall these results provide clear support that Innovativeness, Proactiveness, and Risk Taking exerts a not significant and negative effect on Differentiation -Firm Performance relationship.

\section{Summary of Hypothesis Testing}

Table 1 below summarized the hypothesis test using SMART-PLS3.

Table 1. Result of hypothesis testing

\begin{tabular}{l|c|c|c|c}
\hline Relationship & $\begin{array}{c}\text { Path } \\
\text { Coefficient }\end{array}$ & t-value & P value & Finding \\
\hline CL $\rightarrow$ Firm Performance & 0.241 & 2.809 & 0.005 & H1 Supported \\
\hline Differentiation $\rightarrow$ Firm Performance & 0.480 & 5.342 & 0.000 & H1 Supported \\
\hline $\begin{array}{l}\text { Higher level of Innovativeness } \rightarrow \text { weaker } \\
\text { relationship CL - Firm Performance }\end{array}$ & -0.089 & 0.745 & 0.457 & H3 Supported \\
\hline $\begin{array}{l}\text { Higher level of Innovativeness } \rightarrow \text { stronger } \\
\text { relationship Differentiation - Firm Performance }\end{array}$ & -0.163 & 1.165 & 0.244 & H4 not Supported \\
\hline $\begin{array}{l}\text { Higher level of Proactiveness } \rightarrow \text { stronger relationship } \\
\text { CL - Firm Performance }\end{array}$ & -0.108 & 0.914 & 0.361 & H5 not Supported \\
\hline $\begin{array}{l}\text { Higher level of Proactiveness } \rightarrow \text { stronger relationship } \\
\text { Differentiation - Firm Performance }\end{array}$ & -0.118 & 1.039 & 0.299 & H6 not Supported \\
\hline $\begin{array}{l}\text { Higher level of Risk Taking } \rightarrow \text { stronger relationship } \\
\text { CL - Firm Performance }\end{array}$ & 0.041 & 0.244 & 0.807 & H7 Supported \\
\hline $\begin{array}{l}\text { Higher level of Risk Taking } \rightarrow \text { stronger relationship } \\
\text { Differentiation - Firm Performance }\end{array}$ & -0.010 & 0.067 & 0.946 & H8 not Supported \\
\hline
\end{tabular}

Note: *Significant at 0.05(1-tailed)

\section{Discussion and Conclusion}

$\mathrm{CL}$ and Differentiation strategy is significantly related to Firm Performance. These findings consistent with (Lechner \& Gudmundsson, 2014) previous study. Secondly, the results revealed that Innovativeness mediate the relationship between CL strategy and firm performance. In higher innovativeness level it entails a weaker relationship between CL and Firm Performance. This finding support (O'Brien et al., 2003; Shukla, Sivasankaran \& Dasgupta 2018) that small firms with a local CL tend to be at the lower end of the innovativeness scale. Surprisingly, innovativeness was not moderate the relationship between differentiation strategy and firm performance. A further possible explanation 
for this could be that small business has a resource constrained and incompatibility. Proactiveness negatively moderate for both relationship between CL and firm performance and Diff and firm performance, because small catering firm are not in the state of aggressively compete with other firms due to resource-matching constraint that resulted to low competitive advantage and lack of matching strategy to available resource. Higher Risk Taking level entail a stronger relationship between CL and Firm Performance. The findings support (Allen et al., 2006; Sijabat, 2018) and suggest that CL requires higher upfront investment in order to achieve economic scale. In the relationship between Diff and firm performance, higher Risk Taking level entail a weaker relationship, and lower risk taking level entail a stronger relationship. This suggests that it will need low levels of risk-taking to grab business-related chances with regard to strategic actions in the face of uncertainty.

The practical significance of these findings suggests that the owner and managers and decision makers within SMEs catering firm aiming to improve financial and non-financial should use competitive strategy differentiation. The findings also suggest that SMEs should focus their energies on creating resource-matching strategy and the adoption of CL strategy with higher level of risk taking.

\section{References}

Allen, R., Helms, M, Takeda, M., \& White, C. (2006). A comparison of competitive strategies in Japan and the United States. SAM Advanced Management Journal, 71(1), 24.

Block, J. H., Kohn, K., Miller, D., \& Ullrich, K. (2015). Necessity entrepreneurship and competitive strategy. Small Business Economics, 44(1), 37-54. https://doi.org/10.1007/s11187-014-9589-x

Blumentritt, T., \& Danis, W. M. (2006). Business strategy types and innovative practices. Journal of Managerial Issues, 274-291.

Covin, J. G., \& Lumpkin, G.T. (2011). Entrepreneurial orientation theory and research: Reflections on a needed $\begin{array}{llll}\text { construct. Entrepreneurship Theory and } & \text { 855-872. }\end{array}$ https://doi.org/10.1111/j.1540-6520.2011.00482.x

Covin, J. G., \& Slevin, D. P. (1989). Strategic management of small firms in hostile and benign environments. Strategic Management Journal, 10(1), 75-87. https://doi.org/10.1002/smj.4250100107

Covin, J. G., \& Slevin, D. P. (1991). A conceptual model of entrepreneurship as firm behavior. Entrepreneurship: Critical Perspectives on Business and Management, 3, 5-28.

Covin, J. G., \& Wales, W. J. (2012). The measurement of entrepreneurial orientation. Entrepreneurship Theory and Practice, 36(4), 677-702. https://doi.org/10.1111/j.1540-6520.2010.00432.x

Dess, G. G., \& Lumpkin, G. T. (2005). The role of entrepreneurial orientation in stimulating effective corporate entrepreneurship. The Academy of Management Executive, 19(1), 147-156. https://doi.org/10.5465/ame.2005.15841975

Dess, G. G., Lumpkin, G. T., \& Covin, J. G. (1997). Entrepreneurial strategy making and firm performance: Tests of contingency and configurational models. Strategic Management Journal, 677-695. https://doi.org/10.1002/(SICI)1097-0266(199710)18:9<677::AID-SMJ905>3.0.CO;2-Q

Dew, N., Sarasathy, S., Read, S., \& Wiltbank, R. (2009). Affordable loss: Behavioral economic aspects of the plunge decision. Strategic Entrepreneurship Journal, 3(2), 105-126. https://doi.org/10.1002/sej.66

George, B., \& Marino, L. D. (2011). The epistemology of entrepreneurial orientation: Conceptual formation, modeling, and operationalization. Entrepreneurship Theory and Practice, 35(5), 989-1024. https://doi.org/10.1111/j.1540-6520.2011.00455.x

Grant, R. M. (2005). Contemporary Strategy Analysis: Concepts, Techniques, Applications. Blackwell Publishers Ltd, Oxford, UK.

Green, K. M., Covin, J. G., \& Slevin, D. P. (2008). Exploring the relationship between strategic reactiveness and entrepreneurial orientation: The role of structure-style fit. Journal of Business Venturing, 23(3), 356-383. https://doi.org/10.1016/j.jbusvent.2007.01.002

Hair, J. F., Jr, Hult, G. T. M., Ringle, C., \& Sarstedt, M. (2014). A primer on partial least squares structural equation modeling (PLS-SEM). Sage Publications.

Henseler, J., Ringle, C. M., \& Sarstedt, M. (2015). A new criterion for assessing discriminant validity in variance-based structural equation modeling. Journal of the Academy of Marketing Science, 43(1), 115-135. 
https://doi.org/10.1007/s11747-014-0403-8

Hughes, M., \& Morgan, R. E. (2007). Deconstructing the relationship between entrepreneurial orientation and business performance at the embryonic stage of firm growth. Industrial Marketing Management, 36(5), 651-661. https://doi.org/10.1016/j.indmarman.2006.04.003

Jing, F. F., \& Avery, G. C. (2016). Missing Links In Understanding The Relationship Between Leadership and Organizational Performance. The International Business \& Economics Research Journal (Online), $15(3), 107$. https://doi.org/10.19030/iber.v15i3.9675

Lechner, C., \& Gudmundsson, S. V. (2014). Entrepreneurial orientation, firm strategy and small firm performance. International Small Business Journal, 32(1), 36-60. https://doi.org/10.1177/0266242612455034

Lumpkin, G. T., \& Dess, G. G. (1996). Clarifying the entrepreneurial orientation construct and linking it to performance. Academy of Management Review, 21(1), 135-172. https://doi.org/10.5465/amr.1996.9602161568

Lumpkin, G. T., \& Dess, G. G. (2001). Linking two dimensions of entrepreneurial orientation to firm performance: The moderating role of environment and industry life cycle. Journal of Business Venturing, 16(5), 429-451. https://doi.org/10.1016/S0883-9026(00)00048-3

Lyon, D. W., Lumpkin, G. T., \& Dess, G. G. (2000). Enhancing entrepreneurial orientation research: Operationalizing and measuring a key strategic decision making process. Journal of Management, 26(5), 1055-1085. https://doi.org/10.1177/014920630002600503

Mahmood, R., \& Hanafi, N. (2013). Entrepreneurial orientation and business performance of women-owned small and medium enterprises in malaysia: competitive advantage as a mediator. International Journal of Business and Social Science, 4(1).

Miller, D. (1988). Relating Porter's business strategies to environment and structure: Analysis and performance implications. Academy of Management Journal, 31(2), 280-308. https://doi.org/10.2307/256549

Miller, K. D. (2007). Risk and rationality in entrepreneurial processes. Strategic Entrepreneurship Journal, 1(1-2), 57-74. https://doi.org/10.1002/sej.2

Miller, D., \& Friesen, P. H. (1982). Innovation in conservative and entrepreneurial firms: Two models of strategic momentum. Strategic Management Journal, 3(1), 1-25. https://doi.org/10.1002/smj.4250030102

Miller, D., \& Friesen, P. H. (1986). Porter's (1980) generic strategies and performance: an empirical examination with American data: part I: testing Porter. Organization Studies, 7(1), 37-55. https://doi.org/10.1177/017084068600700103

O'Brien, J. P., Folta, T. B., \& Johnson, D. R. (2003). A real options perspective on entrepreneurial entry in the face of uncertainty. Managerial and Decision Economics, 24(8), 515-533. https://doi.org/10.1002/mde.1115

Porter, M. E. (1980). Industry structure and competitive strategy: Keys to profitability. Financial Analysts Journal, 36(4), 30-41. https://doi.org/10.2469/faj.v36.n4.30

Rauch, A., Wiklund, J., Lumpkin, G. T., \& Frese, M. (2009). Entrepreneurial orientation and business performance: An assessment of past research and suggestions for the future. Entrepreneurship Theory and Practice, 33(3), 761-787. https://doi.org/10.1111/j.1540-6520.2009.00308.x

Richard, O. C., Barnett, T., Dwyer, S., \& Chadwick, K. (2004). Cultural diversity in management, firm performance, and the moderating role of entrepreneurial orientation dimensions. Academy of Management Journal, 47(2), 255-266. https://doi.org/10.5465/20159576

Runyan, R., Droge, C., \& Swinney, J. (2008). Entrepreneurial orientation versus small business orientation: what are their relationships to firm performance?. Journal of Small Business Management, 46(4), 567-588. https://doi.org/10.1111/j.1540-627X.2008.00257.x

Sabir, S., \& Khan, A. (2018). Impact of Political Stability and Human Capital on Foreign Direct Investment in East Asia \& Pacific and South Asian Countries. Asian Journal of Economic Modelling, 6(3), 245-256. https://doi.org/10.18488/journal.8.2018.63.245.256

Seddighi, H., \& Yoon, I. H. (2018). Stock Market Efficiency and Price Limits: Evidence from Korea's Recent Expansion of Price Limits. Asian Journal of Economics and Empirical Research, 5(2), 191-200. https://doi.org/10.20448/journal.501.2018.52.191.200

Senam, N., Akpan, U. U., \& Mboho, M. (2017). Freedom of Information Act 2011 and Press Freedom: Challenges 
and Prospects for Media Practice in Nigeria. International Journal of Emerging Trends in Social Sciences, 1(2), 74-80. https://doi.org/10.20448/2001.12.74.80

Setiyawati, H., Iskandar, D., \& Basar, Y. S. (2018). The Quality of Financial Reporting through Increasing the Competence of Internal Accountants and Accrual Basis. International Journal of Economics, Business and Management Studies, 5(1), 31-40. https://doi.org/10.20448/802.51.31.39

Shukla, A., Sivasankaran, N., \& Dasgupta, S. A. (2018). Do Board Characteristics Impact the Market Performance of Indian Banks? Asian Economic and Financial Review, 8(11), 1365-1383. https://doi.org/10.18488/journal.aefr.2018.811.1365.1383

Sijabat, R. (2018). Understanding Behavioral Economics: A Narrative Perspective. Asian Development Policy Review, 6(2), 77-87. https://doi.org/10.18488/journal.107.2018.62.77.87

Stevenson, H. H., \& Jarillo, J. C. (2007). A paradigm of entrepreneurship: Entrepreneurial management. Entrepreneurship: Concepts, Theory and Perspective, 155-170. https://doi.org/10.1007/3-540-48543-0_7

Teece, D. J., Pisano, G. P., \& Shuen, A. (1997). Dynamic capabilities and strategic management. Strategic Management Journal, 509-533. https://doi.org/10.1002/(SICI)1097-0266(199708)18:7<509::AID-SMJ882>3.0.CO;2-Z

Thornhill, S., \& Amit, R. (2003). Learning about failure: Bankruptcy, firm age, and the resource-based view. Organization Science, 14(5), 497-509. https://doi.org/10.1287/orsc.14.5.497.16761

Tzokas, N., Carter, S., \& Kyriazopoulos, P. (2001). Marketing and entrepreneurial orientation in small firms. Enterprise and Innovation Management Studies, 2(1), 19-33. https://doi.org/10.1080/14632440110056625

Wales, W. J., Gupta, V. K., \& Mousa, F-T. (2013). Empirical research on entrepreneurial orientation: An assessment and suggestions for future research. International Small Business Journal, 31(4), 357-383. https://doi.org/10.1177/0266242611418261

Wiklund, J. (2006). The sustainability of the entrepreneurial orientation-performance relationship. Entrepreneurship and the Growth of Firms, 7(3), 141-155.

Zahra, S. A., Sapienza, H. J., \& Davidsson, P. (2006). Entrepreneurship and dynamic capabilities: A review, model and research agenda. Journal of Management Studies, 43(4), 917-955. https://doi.org/10.1111/j.1467-6486.2006.00616.x 